\title{
Evaluasi Program Mahasiswa Wirausaha Tahun 2018 di Universitas Negeri Padang
}

\author{
Anisa Endriani, Hasrul \\ Prodi Pendidikan Pancasila dan Kewarganegaraan \\ Universitas Negeri Padang \\ E-mail: anisaendriani97@gmail.com
}

\begin{abstract}
ABSTRAK
Penelitian ini bertujuan untuk mengevaluasi implementasi kebijakan Program Mahasiswa Wirausaha (PMW) di Universitas Negeri padang, mengidentifikasi faktor-faktor keberhasilan kegagalan dan kendala dalam pelaksanaan PMW tahun 2018 di UNP, serta upaya dalam mengatasi kendala tersebut. Penelitian ini menggunakan penelitian deskriptif kualitatif dengan metode deskriptif. Pemilihan informan dilakukan dengan teknis purposive sampling dengan informan penelitian sebanyak 15 orang informan yaitu ketua pelaksana, biro akademik dan kemahasiswaan, pegawai UPT PKK, dosen pembimbing PMW, sekretaris umum UPKK, dan mahasiswa penerima dana PMW tahun 2018 di UNP. Hasil penelitian menunjukkan bahwa pelaksanaan program mahasiswa wirausaha tahun 2018 di UNP belum maksimal atau belum sesuai dengan perencanaan program. Dimana masih terdapat beberapa kendala dalam pelaksanaan program seperti banyaknya tahapan pelaksanaan yang belum terealisasikan dan juga waktu dalam pelaksanaan yang kurang tepat. Faktor faktor yang menyebabkan keberhasilan PMW tahun 2018 di UNP antara lain adalah faktor kemauan dan kemampuan, tekat yang kuat dan kerja keras, kesempatan dan peluang, pengalaman dalam pekerjaan. Sementara faktor kegagalannya adalah tidak kompeten dalam hal manajerial, kurang berpengalaman, kurang dapat mengendalikan keuangan, gagal dalam perencanaan, lokasi yang kurang memadai, masa studi. Upaya yang telah dilaksanakan dalam mengatasi kendala adalah adanya lembaga khusus dalam mengelola program mahasiswa wirausaha tahun selanjutnya dan perubahan sistem pelaksanaan serta syarat pendaftaran program mahasiswa wirausaha tahun selanjutnya.
\end{abstract}

Kata Kunci: evaluasi, Kewirausahaan, program mahasiswa wirausaha

\section{ABSTRACT}

This research aims to evaluate the implementation of the Entrepreneurial Student Program (PMW) policy at Universitas Negeri Padang, identify the factors of success and failure in the implementation of the 2018 PMW at UNP, and efforts to overcome these obstacles. This research uses descriptive qualitative research with descriptive methods. The selection of informants was carried out using a purposive sampling technique with 15 informants, namely the chief executive, academic and student bureau, UPT PKK staff, PMW 
supervisor lecturers, UPKK general secretary, and students receiving 2018 PMW funds at UNP. The results showed that the implementation of entrepreneurship student programs in 2018 at UNP was not optimal or not in accordance with program planning. There were still some obstacles in the implementation of the program such as the many stages of implementation that had not been realized and also the time in implementation that was not right. The factors that led to success PMW 2018 at UNP include willingness and ability factors, strong determination and hard work, opportunities and opportunities, work experience. Meanwhile the failure factors PMW 2018 at UNP are incompetent in managerial matters, less experienced, less able to control financial, failure in planning, inadequate location, study period. The efforts that have been carried out in overcoming the obstacles are the existence of a special institution in managing the entrepreneurial student program the following year and the change in the implementation system and the registration requirements for the next year student entrepreneurship program.

Keywords : : evaluation, entrepreneurship, student entrepreneurship program

cc) (D) () This work is licensed under the Creative Commons Attribution-ShareAlike 4.0 International License. author.

\section{PENDAHULUAN}

Saat ini di Indonesia seseorang yang berpendidikan tinggi belum terjamin mendapatkan pekerjaan yang layak, bahkan masih banyak terdapat tamatan dari Perguruan Tinggi yang belum mempunyai pekerjaan (Saputra, 2016: 2). Sebagian besar lulusan perguruan tinggi masih berorientasi sebagai pencari kerja (job seeker) dari pada sebagai pencipta kerja (job creator). Oleh karena itu pendidikan tinggi di Indonesia perlu lebih menyiapkan lulusannya menjadi sarjana yang mampu hidup mandiri, berkreasi, memanfaatkan sains dan teknologi serta seni yang telah dipelajarinya. (Nurjoko, 2014: 513).

Permasalahan tersebut membuat pemerintah melalui Direktur jendral pendidikan Tinggi Kementrian Pendidikan dan Kebudayaan menjalankan sebuah program baru yang diharapkan dari program ini yaitu agar mampu melahirkan pusatpusat kewirausahaan di Perguruan Tinggi di Indonesia. Program tersebut dinamakan Program Mahasiswa Wirausaha atau PMW.

Menurut Dikti (2013:2), PMW merupakan bagian dari strategi pendidikan kewirausahaan di Perguruan Tinggi. PMW adalah suatu program yang memfasilitasi para mahasiswa untuk memulai berwirausaha dengan basis ilmu pengetahuan. Fasilitas yang diberikan meliputi pendidikan dan pelatihan kewirausahaan, magang, penyusunan rencana bisnis, dukungan, permodalan dan pendampingan usaha serta keberlanjutan usaha. PMW dapat dikatakan sebagai sarana dan prasarana dalam praktek nyata berwirausaha di perguruan tinggi. (Saputra, 2016: 7). 
Program ini diharapkan mampu mendukung visi misi pemerintah dalam mewujudkan kemandirian bangsa melalui penciptaan lapangan kerja dan memberdayakan lapangan pekerjaan yang mampu mengurangi angka pengangguran terdidik di Indonesia dan mampu membangkitkan lagi perekonomian Indonesia. Selain itu PMW ini juga bertujuan untuk meningkatkan minat dan kemampuan berwirausaha mahasiswa. Dengan adanya peningkatan minat dan kemampuan berwirausaha maka diharapkan dapat berdampak positif terhadap kelangsungan usaha mahasiswa penerima dana PMW. (Saputra, 2016: 2).

PMW bertujuan untuk memberikan bekal pengetahuan keterampilan, dan sikap atau jiwa kewirauusahaan (entrepreurship) berbasis Iptek kepada para mahasiswa agar dapat mengubah mindset dari pencari kerja pencipta lapangan pekerjaan serta menjadi pengusaha yang tangguh dan sukses menghadapi persaingan global. Program ini juga bertujuan mendorong kelembagaan atau unit kewirausahaan di perguruan tinggi agar dapat mendukung pengembangan program-program kewirausahaan Sebagai hasil akhir, diharapkan terjadinya penurunan angka pengangguran lulusan pendidikan tinggi. ( Saputra, 2016: 7).

Universitas Negeri Padang merupakan salah satu universitas yang turut serta dalam menyukseskan pelaksanaan program ini. Pelaksanaan PMW di UNP sudah dilaksanakan sejak tahun 2009 hingga sekarang. Berdasarkan observasi awal penulis dilapangan, penulis melihat pelaksanaan PMW di UNP belum berjalan dengan maksimal. Seperti masih ada kelompok penerima dana PMW yang tidak menjalankan usahanya sesuai dengan tujuan awal dan masih ditemukan kelompok yang usahanya berhenti ditengah jalan.

Fokus penulis terhadap kegiatan program mahasiswa wirausaha ini adalah pada tahun 2018. Sebab bermula dari penulis melihat dilapangan, banyaknya peserta program yang tidak menjalankan usahanya sesuai dengan tujuan awal. Banyak usaha yang berhenti ditengah jalan. Panitia pelaksana program mahasiswa wirausaha tahun 2018 di UNP mengemukakan kendala utama dalam pelaksanaan PMW di UNP ini adalah selesainya jangka waktu pelaksanaan maka berefek berhenti pula kegiatan usaha yang dijalankan. Dilihat dari tujuan PMW ini tentu saja hal ini bertentangan dengan tujuan PMW di UNP.

Salah satu tujuan dari PMW ini adalah peningkatan kemampuan dan kemandirian mahasiswa dalam mengembangkan usaha berkelanjutan secara terus menerus dan menciptakan wirausahawan yang berkarakter entrepreneurship. Seharusnya peserta PMW yang didanai sudah dijalankan akan terus berlanjut, meskipun jangka waktu pelaksanaan program berakhir sehingga manfaat yang diperoleh mahasiswa wirausaha tidak berhenti. Namun yang terjadi dilapangan PMW yang didanai banyak yang tidak melanjutkan programnya setelah dilaksanakan monitoring dan evaluasi oleh panitia pelaksana. Untuk mengetahui perkembangan program mahasiswa wirausaha tahun $2018 \mathrm{di}$ UNP dapat dilihat melalui tabel berikut ini : 
Data Peserta Penerima Dana PMW tahun 2018 di UNP

\begin{tabular}{|c|c|c|c|c|}
\hline No & Jenis usaha & Kelompok yang didanai & Jalan & Tutup \\
\hline 1. & Jasa & 17 & 7 & 10 \\
\hline 2. & Produk & 43 & 4 & 39 \\
\hline Total & 2 & 60 & 11 & 49 \\
\hline
\end{tabular}

Sumber: Biro Akademik Kemahasiswaan dan Observasi kelapangan

Berdasarkan tabel diatas terdapat 60 kelompok usaha yang lolos pada tahun 2018. Jenis usaha program wirausaha tahun 2018 ini berbentuk produk dan jasa, usaha produk ada 43 kelompok namun dari 43 kelompok usaha produk hanya 4 kelompok usaha yang masih lanjut hingga sekarang dan 39 kelompok lagi yang sudah berhenti. Sedangkan usaha jasa sebanyak 17 kelompok. Dari 17 kelompok hanya 7 kelompok usaha yang masih jalan dan 10 kelompok usaha jasa yang sudah berhenti. Dana yang didapatkan masing-masing kelompok juga berbeda-beda, namun dari total keseluruhan 60 kelompok yang didanai hanya 11 kelompok yang usahanya berjalan hingga sekarang dan 49 kelompok lagi sudah berhenti atau tidak melanjutkan lagi usahanya.

Berdasarkan penelitian terdahulu oleh Juwita yang berjudul "Faktor penyebab ketidakefektifan Program Mahasiswa Wirausaha dalam Menciptakan Wirausahawan di Universitas negeri Padang". Hasil penelitian ini menjelaskan bahwa ada empat faktor yang menyebabkan tidak efektifnya pelakasanaan PMW dalam menciptakan wirausahawan di UNP. Ketidakefektifan tersebut berdasarkan dari diri peserta dan lingkungan sosial PMW yaitu sikap mental, komitmen, penerapan nilai-nilai wirausaha lainnya, seperti kreativitas inovasi dan berani mengambil resiko, keterbatasan
Volume 3 No. 12020

persiapan peserta

dalam berwirausaha.

Penelitian selanjutnya oleh Widarsih yang berjudul "Efektivitas Program Mahasiswa Wirausaha dalam Meningkatkan Minat dan Kemampuan Berwirausaha Mahasiswa UNY". Hasil penelitian ini menjelaskan bahwa pelaksanaan fasilitisi PMW maupun pelatihan kewirausahaan di UNY cukup baik namun peningkatan ratarata kemampuan berwirausaha mahasiswa UNY dalam implementasi program kurang. Sehingga dapat dikatakan kurang efektif. Penelitian ini mengevaluasi bagaimana PMW dalam meningkatkan minat dan kemampuan berwirausaha mahasiswa UNY.

Berdasarkan

penelitian terdahulu, maka penulis perlu melakukan penelitian lebih lanjut dengan fokus dan lokasi yang berbeda dengan penelitian yang sebelumnya. Yaitu penelitian ini terkait dengan evaluasi PMW tahun 2018 di UNP. Berdasarkan data jumlah penerima PMW tahun 2018 di UNP, dalam tulisan ini peneliti memfokuskan pada Evaluasi Program Mahasiswa Wirausaha (PMW) tahun 2018 di UNP dengan pertimbangan keterbatasan data dan informasi terkait program mahasiswa wirausaha dari tahun 2012 hingga 2017. Kemudian pada tahun 2019 belum dapat dilihat sejauh mana keberhasilan dan kegagalannya, karena dalam tahap proses pelaksanaan.

\section{METODE PENELITIAN}

Jenis penelitian ini adalah
penelitian kualitatif $\begin{array}{r}\text { dengan } \\ \text { menggunakan metode deskriptif. }\end{array}$
Karena dalam penelitian ini
menggunakan metode observasi,


wawancara dan dokumentasi. Strategi dalam penelitian ini adalah studi kasus tunggal karena hanya berlaku pada Evaluasi Program Mahasiswa wirausaha (PMW) tahun 2018 di Universitas Negeri Padang. Penentuan informan dalam penelitian ini melalui purposive sampling/sample bertujuan. Purposive Sampling yaitu penempatan informan penelitian secara sengaja sesuai dengan tujuan penelitian. Melalui teknik ini, penulis bisa benar-benar mengakui bahwa orang-orang yang dipilih dapat memberikan informasi yang diinginkan. Pertimbangan tertentu yang ditetapkan oleh peneliti sesuai dengan kepentingan penelitian. Alat pengumpulan data utama dalam penelitian ini adalah observasi, alat perekam, buku catatan wawancara, pedoman wawancara dan alat-alat dokumentasi yang didukung oleh alat pengumpulan data lainnya untuk mencatat subjek yang diteliti.

\section{HASIL DAN PEMBAHASAN}

Berdasarkan hasil penelitian yang peneliti temukan dilapangan dari 60 kelompok PMW yang didanai pada tahun 2018 di UNP hanya 11 kelompok yang usahanya masih berjalan hingga sekarang dan 49 kelompok lagi usahanya yang sudah berhenti. Sejalan dengan tema yang peneliti angkat yaitu Evaluasi program mahasiswa wirausaha (PMW) tahun 2018 di Universitas negeri padang, evaluasi program menurut Musa (2005) dalam (Iskandar, 2012) mengatakan bahwa evaluasi program adalah suatu kegiatan untuk memperoleh gambaran tentang keadaan suatu objek yang dilakukan secara terencana, sistematis dengan arah dan tujuan yang jelas. Tujuan dari evaluasi program ini adalah untuk menentukan relevansi dan ketercapaian tujuan, efesiensi, efektifitas, dampak dan keberlanjutannya.

Evaluasi suatu program merupakan salah satu elemen penting dalam kebijakan karena menilai sampai sejauh mana tingkat keberhasilan dan kegagalan pelaksanaan program. Tahap evaluasi dilakukan baik terhadap proses maupun hasil implementasi kebijakan. Penilaian terhadap proses dan hasil kebijakan di fokuskan melihat pengaruh atau dampak kebijakan sejauh mana kebijakan PMW di UNP mampu menciptakan lapangan pekerjaan.

\section{Pelaksanaan PMW tahun 2018 di UNP}

Pelaksanaan adalah suatu tindakan atau pelaksanaan dari sebuah rencana yang sudah disusun secara matang dan terperinci sementara implementasi biasanya dilakukan setelah perencanaan dianggap siap. Pelaksanaan PMW pada tahun 2018 di UNP belum efektif karena tidak sesuai dengan rencana awal. Seperti masih adanya prosedur yang belum terlaksanakan dengan maksimal diantaranya adalah sosialisasi yang kurang booming, masih banyak mahasiswa yang belum mengetahui informasi PMW sehingga banyak mahasiswa yang tidak berpeluang mengikuti PMW tahun 2018 di UNP, magang yang tidak terlaksana, presentasi yang kurang efektif dan juga diklat yang belum maksimal dilaksanakan, dan monitoring yang kurang optimal dilaksanakan. Meskipun demikian terdapat faktorfaktor yang memberikan keberhasilan dan kegagalan dalam pelaksanaan PMW di UNP. 
Faktor Keberhasilan PMW tahun 2018 di UNP

Berdasarkan hasil temuan dari 11 kelompok usaha yang masih berjalan dipengaruhi oleh beberapa faktor keberhasilan diantaranya yaitu (Suryana, 2013:110):

Kemauan dan kemampuan

Kemauan dan kemampuan mahasiswa merupakan faktor yang paling utama dalam menentukan kesuksesan dalam berwirausaha, orang yang memiliki kemauan dan dilengkapi oleh kemampuan akan menjadi orang yang sukses. Kemauan tidak cukup bila tidak dilengkapi oleh kemampuan. Beberapa mahasiswa memiliki kemampuan dan kemauan menjadi wirausahaan. Mahasiswa yang mempunyai kemampuan dan kemauan dibuktikan oleh usaha 'Be'Seleb'. Meskipun sudah empat kali mengajukan proposal, baru tahun 2018 diterima dan didanai. Ketika terkendala dalam menjalankan usaha, maka butuh kemampuan menyelesaikan masalah, manajemen resiko dan alternative pemecahan masalah. Sehingga usaha yang digeluti dapat berjalan dan bertahan.

Tekat yang kuat dan kerja keras

Orang yang memiliki tekat yang kuat dan kemauan untuk bekerja keras akan menjadi wirausahawan sukses. Kuncinya mahasiswa mesti memeliki tekad dan kerja keras untuk membangun dan mengembangkan usaha sehingga luaran dari Program Mahasiswa Wirausaha dapat tercapai. Tekat yang kuat dan kerja keras dibuktikan oleh usaha 'Madani Cendekia' yang mana usaha ini telah berjalan dan mendapatkan dana pengembangan selama tiga tahun. Tim
Madani selalu kerja keras dalam mengembangkan usaha sampai usaha berkembang luas hingga sampai sekarang.

kesempatan dan peluang

Peluang ada jika menciptakan peluang itu sendiri bukan mencari-cari atau menunggu peluang yang akan datang kepada kita. Hal ini dapat dibuktikan ketika orientasi mahasiswa berwirausaha untuk mengembangkan ilmunya, sehingga tamat kuliah atau sebelum tamat kuliah dapat membuka lapangan pekerjaan sehingga dapat menjadi modalkerja untuk mahasiswa. Seperti yang di implementasikan oleh usaha 'public speaking centre', 'madani cendekia', 'babaju rancak', dan 'mie PBB'. Keseluruhan usaha ini meskipun pengelolanya sudah tamat kuliah usaha sampai saat ini masih berjalan dan berkembang.

Pengalaman dalam pekerjaan

Pengalaman dan pekerjaan merupakan sesuatu yang menjadi pendorong didalam pengembangan sebuah usaha. (Suryana, 2013:110), Hal ini dibuktikan oleh analisis usaha yang masih bertahan sampai saat ini seperti usaha yang berjudul 'Medani cendekia', 'seleb salon', 'MIE PBB' dan 'Babaju Rancak', serta 'Public Speaking Centre'.

\section{Faktor kegagalan PMW tahun 2018}

Berdasarkan hasil temuan dari 49 kelompok usaha yang gagal atau sudah berhenti dipengaruhi oleh beberapa faktor kegagalan menurut Zimmerer (1996) dalam suryana (2013:110) diantaranya yaitu:

Tidak kompeten dalam hal manajerial

Tidak kompeten atau tidak memiliki kemampuan dan 
pengetahuan untuk mengelola usaha merupakan faktor penyebab utama yang membuat perusahan kurang berhasil, seperti manajemen waktu mahasiswa yang berbeda dengan sesama anggota dalam usaha program mahasiswa wirausaha pada tahun 2018 di UNP manajemen administrasi yang kurang bagus, manajemen pemasaran yang kurang dikuasai oleh anggota kelompok.

\section{Kurang berpengalaman}

Seorang Wirausahawan sebaiknya mempunyai pengalaman dalam menjalankan usahanya, baik dalam kemampuan teknik menvisulisasikan usaha, mengkoordinasikan, mengelola sumber daya maupun mengintegrasikan operasi perusahaan. Jika seorang wirausahawan kurang berpengalaman dalam menjalankan usaha, faktor ini dapat mempengaruhi kegagalan sebuah usaha.

\section{Kurang dapat mengendalikan keuangan}

Agar perusahaan dapat berhasil dengan baik, faktor yang paling utama dalam keuangan adalah memelihara aliran kas, mengatur pengeluaran dan pemasukan secara cermat. Kekeliruan dalam pemeliharaan aliran kas akan menghambat operasional perusahaan dan mengakibatkan perusahaan tidak lancar.

\section{Gagal dalam perencanaan}

Perencanaan merupakan titik awal dari suatu kegiatan, sekali gagal dalam perencanaan maka akan mengalami kesulitan dalam pelaksanaan. Hal ini dibuktikan oleh usaha 'Tahu Brekele'. Usaha berhenti karena telat memberikan laporan sehingga dana kedua tidak cair, dan juga usaha tidak sesuai rencana, usaha berhenti ditengah jalan karena kurang kerjasama dalam tim untuk menjalankan usaha tersebut.

\section{Lokasi yang kurang memadai}

Lokasi usaha yang strategis merupakan faktor yang menentukan keberhasilan usaha. Lokasi yang tidak strategis dapat mengakibatkan perusahaan sukar beroperasi karena kurang efisien.

\section{Kurangnya pengawasan peralatan}

Pengawasan yang erat kaitan dengan efisiensi dan efektivitas. Kurangnya pengawasan dapat mengakibatkan penggunaan peralatan secara tidak efisien dan tidak efektif.

Sikap kurang sungguh-sungguh dalam berusaha

Sikap yang setengah-setengah terhadap usaha akan mengakibatkan usaha yang dilakukan labil dan gagal dengan sikap setengah hati, kemungkinan terjadi gagal menjadi lebih besar.

Ketidakmampuan dalam melakukan peralihan/transisi kewirausahan

Wirausahawan yang kurang siap menghadapi dan melakukan perubahan tidak menjadi wirausahaan yang berhasil. Keberhasilan dalam berwirausaha hanya bisa diperoleh apabila berani mengadakan perubahan dan mampu membuat peralihan waktu (Zimmerer dalam Suryana, 2013:110). Hal ini dibuktikan oleh analisis usaha yang tidak bertahan lagi atau sudah berhenti seperti usaha yang berjudul 'tahu brekele UTS' (Udang Telur sosis), 'UNP Creative Advertising', 'den cubitkan' (Dendeng Pucuak Ubi Raso Ikan), 'windows patchwork', 'souvenir Baralek'. 
Faktor kegagalan yang paling dominan adalah kurangnya pengawasan dari pihak panitia pelaksana program, sehingga menyebabkan usaha gagal dan berhenti begitu saja. Oleh karena itu perlu dibentuk sebuah lembaga yang dapat memantau usaha mahasiswa yang telah didanai karena kurangnya pengalaman, ilmu, wawasan mahasiswa dari usaha yang dijalankan. Dibutuhkan panitia yang mampu meningkatkan pelatihan bagi semua jurusan di Universitas Negeri padang agar mendapatkan mata kuliah KWU (kewirausahaan).

Upaya dalam mengatasi kendalakendala dalam pelaksanaan PMW tahun 2018 di UNP

Pertama adanya lembaga khusus dalam mengelola program mahasiswa wirausaha tahun selanjutnya. Upaya ini telah disampaikan oleh ketua pelaksana program mahasiswa wirausaha di UNP bahwa PMW tahun selanjutnya akan dikelola oleh UPT PKK yang merupakan lembaga khusus kewirausahaan, sehingga program mahasiswa wirausaha dapat dikelola lebih baik lagi oleh bidang yang bersangkutan. Kedua, adanya perubahan sistem pelaksanaan dan syarat pendaftaran program mahasiswa wirausaha tahun selanjutnya.

$\begin{array}{rcr}\text { Selain } & \text { perubahan } & \text { sistem } \\ \text { pelaksanaan } & \text { dari } & \text { kabag }\end{array}$ kemahasiswaan beralih ke UPT PKK UNP, program mahasiswa wirausaha di UNP akan merubah sedikit syarat dari peserta yang ingin mengikuti program PMW. Seperti magang di UKM akan dilakukan, presentasi usaha akan dilakukan secara langsung tatap muka, tidak lagi melalui video dokumenter dan juga masa semester mahasiswa yang ingin mengikuti program mahasiswa wirausaha di UNP yang biasanya mulai dari semester empat, untuk tahun- tahun berikutnya mahasiswa yang ingin mengikuti program mahasiswa wirausaha di UNP di mulai dari semester dua.

\section{KESIMPULAN}

Berdasarkan uraian hasil penelitian maka dapat disimpulkan bahwa pelaksanaan program mahasiswa wirausaha tahun 2018 di UNP belum maksimal atau belum sesuai dengan perencanaan program dimana masih terdapat beberapa kendala dalam pelaksanaan program. Beberapa kendala yang ditemukan setelah melakukan penelitian dalam pelaksanaan PMW tahun 2018 di UNP yaitu kurang efektif dalam proses pelaksanaan seperti banyaknya tahapan pelaksanaan yang belum terealisasikan dan juga waktu dalam pelaksanaan yang kurang tepat. Beberapa tahapan pelaksanaan yang tidak terealisasikan seperti sosialisasi kurang maksimal, sosialisasi hanya dilakukan melalui workshop, melalui pamflet dan brosur dikampus, magang di UKM tidak terlaksana, dikarenakan situasi dan kondisi yang tidak memungkinkan. Penyerahan laporan kemajuan dan laporan akhir banyak telat, kurangnya bimbingan dari pembimbing usaha, monitoring dan evaluasi kurang maksimal, monitoring hanya dilakukan dua sampai tiga kali saja, dan expo produk tidak terlaksana. Dari aspek hasil program belum efektif dibuktikan hanya sedikit usaha yang masih berlanjut banyak usaha yang tutup. 
Faktor-faktor

yang

mempengaruhi keberhasilan program mahasiswa tahun 2018 di UNP antara lain kemauan dan kemampuan, tekad yang kuat dan kerja keras, kesempatan dan peluang, dan pengalaman dalam pekerjaan. Selain faktor keberhasilan, ada beberapa faktor kegagalan dari program mahasiswa wirausaha tahun 2018 di UNP antara lain tidak kompeten dalam hal manajerial, kurang berpengalaman baik dalam kemampuan teknik menvisualisasikan usaha, mengkoordinasikan, mengelola sumber daya maupun mengintegrasikan operasi perusahaan, kurang dapat mengendalikan keuangan, gagal dalam perencanaan, lokasi yang kurang memadai, kurangnya pengawasan peralatan, Sikap kurang sungguh-sungguh dalam berusaha, ketidak mampuan dalam melakukan peralihan / transisi kewirausahan. Upaya yang telah dilakukan dalam mengatasi kendala tersebut adalah adanya lembaga khusus dalam mengelola program mahasiswa wirausaha tahun selanjutnya dan juga membuat perubahan sistem pelaksanaan dan syarat pendaftaran program mahasiswa wirausaha tahun selanjutnya.

\section{DAFTAR PUSTAKA}

Juwita, Rahmi. 2017. Faktor Penyebab Ketidakefektifan Program Mahasiswa Wirausaha Dalam Menciptakan Kewirausahawan di Universitas Negeri Padang. [Skripsi]. Padang: Fakultas Ilmu Sosial Universitas Negeri Padang.

Nurjoko, Wibowo. 2014. Rancang Bangun Model Seleksi PMW Berbasis WEB. Seminar Nasional Bisnis dan Teknologi
Suryana. 2013. Kewirausahaan (Kiatkiat menju sukses). Salemba Empat.

Undang-Undang Republik Indonesia No. 20 tahun 2003. Tentang Sistem Pendidikan Nasional. Jakarta: Depdiknas.

Widarsih, Ria. 2012. Efektifitas Program Mahasiswa Wirausaha (PMW) dalam meningkatkan minat dan kemampuan berwirausaha Mahasiwa UNY. [skripsi]. Yogyakarta: Fakultas Ekonomi Universitas Negeri Yogyakarta.

Saputra, Oki Nanda. 2016. Peran PMW dalam Meningkatkan pengetahuan Berwirausaha mahasiswa FT UNP. Jurnal CIVED Vol.4 No.1 2016 